\title{
Effect of Biotin on Activity and Gene Expression of Biotin-Dependent Carboxylases in the Liver of Dairy Cows
}

\author{
G. Ferreira and W. P. Weiss ${ }^{1}$ \\ Department of Animal Sciences, Ohio Agricultural Research and Development Center, The Ohio State University, Wooster 44691
}

\begin{abstract}
Biotin is a cofactor of the gluconeogenic enzymes pyruvate carboxylase (PC) and propionyl-coenzyme A carboxylase (PCC). We hypothesized that biotin supplementation increases the activity and gene expression of PC and PCC and the gene expression of phosphoenolpyruvate carboxykinase (PEPCK) in the liver of lactating dairy cows. Eight multiparous Holstein cows $(40 \pm 2$ $\mathrm{kg} / \mathrm{d}$ of milk yield and $162 \pm 35 \mathrm{~d}$ in milk) were randomly assigned to 1 of 2 diet sequences in a crossover design with two 22-d periods. Treatments consisted of a basal diet (60\% concentrate) containing 0 or $0.96 \mathrm{mg} / \mathrm{kg}$ of supplemental biotin. On d 21 of each period, liver tissue was collected by percutaneous liver biopsy. Activities of $\mathrm{PC}$ and $\mathrm{PCC}$ were determined by measuring the fixation of $\left[{ }^{14} \mathrm{C} \mathrm{O}_{2}\right.$ in liver homogenates. Abundance of mRNA for PCC, PC, and PEPCK was determined by quantitative reverse-transcription PCR. Biotin supplementation did not affect milk production or composition. Biotin supplementation increased the activity of PC but had no effect on PCC activity. Biotin supplementation did not affect the gene expression of PC, PCC, and PEPCK. The increased activity of PC without changes in mRNA abundance may have been caused by increased activation of the apoenzymes by holocarboxylase synthetase. In conclusion, biotin supplementation affected the activity of PC in the liver of lactating dairy cows, but whether biotin supplementation increases glucose production in the liver remains to be determined.
\end{abstract}

Key words: biotin, dairy cow, pyruvate carboxylase, propionyl-coenzyme A carboxylase

\section{INTRODUCTION}

Several studies (Zimmerly and Weiss, 2001; Majee et al., 2003; Ferreira et al., 2007), but not all (Rosendo et al., 2004), have demonstrated that biotin supplementation increases milk production by lactating dairy

Received June 7, 2006.

Accepted October 18, 2006.

${ }^{1}$ Corresponding author: weiss.6@osu.edu cows. Despite these observations, the mechanism by which biotin supplementation increases milk production is still unknown. Glucose supply to the mammary gland is a major determinant of milk yield in lactating dairy cows (Reynolds et al., 1994). Therefore, the increase in milk production by lactating dairy cows whose diets were supplemented with biotin might be related to an increase in gluconeogenesis, presumably in the liver.

Biotin is a cofactor of the gluconeogenic enzymes pyruvate carboxylase (PC, EC 6.4.1.1) and propionyl-coenzyme A (CoA) carboxylase (PCC, EC 6.4.1.3). Pyruvate carboxylase catalyzes the carboxylation of pyruvate to form oxaloacetate, whereas PCC catalyzes the carboxylation of propionyl-CoA to form methylmalonylCoA, a precursor of oxaloacetate. Rodriguez-Melendez et al. (2001) reported lower PCC and PC activities in the liver of biotin-deficient rats than in the liver of biotin-sufficient rats. Mock and Mock (2002) also reported reduced PCC activity in the liver of biotin-deficient rats. Our main hypothesis was that biotin supplementation would increase the activity and expression of genes for the biotin-dependent carboxylases PCC and $\mathrm{PC}$ in the liver of lactating dairy cows.

Increased activities of PC and PCC might result in increased production of oxaloacetate. Phosphoenolpyruvate carboxykinase (PEPCK, EC 4.1.1.32) catalyzes the decarboxylation of oxaloacetate to produce phosphoenolpyruvate, the precursor for glucose synthesis. Phosphoenolpyruvate was synthesized in liver-extract incubations containing PC and PEPCK, but little phosphoenolpyruvate was synthesized in incubations with only PC, resulting in accumulation of oxaloacetate (Keech and Utter, 1963). Baird and Young (1975) observed that the increase in activity of PCC in the liver of dairy cows fed a diet containing $100 \%$ concentrate was accompanied by an increase in the activity of PEPCK. Because of its key role in gluconeogenesis, we expected an increased activity of PEPCK if biotin supplementation increased the production of oxaloacetate. Because the activity of PEPCK is correlated with PEPCK mRNA abundance in dairy cows (Agca et al., 2002), our secondary hypothesis was that biotin supplementation would increase the gene expression of PEPCK in the liver of lactating dairy cows. The objectives of this study were 
to determine the effect of biotin supplementation on the activities of PCC and PC and on the expression of genes for PCC, PC, and PEPCK in the liver of lactating dairy cows.

\section{MATERIALS AND METHODS}

\section{Materials and Reagents}

$\mathrm{NaH}\left[{ }^{14} \mathrm{C}\right] \mathrm{CO}_{3}(5.95 \mathrm{mmol} / \mathrm{L}, 8.4 \mathrm{mCi} / \mathrm{mmol})$ was purchased from American Radiolabeled Chemicals, Inc. (St. Louis, MO). Propionyl-CoA (P5397), disodium ATP (A3377), sodium pyruvate (P2256), acetyl-CoA (A2056), reduced NAD (N8129), and malate dehydrogenase (M7032) were purchased from Sigma (St. Louis, MO). The Bradford Assay Kit (23236) was purchased from Pierce (Rockford, IL). Trizol reagent and reverse-transcription enzyme (Super Script II) were purchased from Invitrogen Corporation (Carlsbad, CA). Ribonuclease inhibitor (RNasin, N2111) was purchased from Promega Corporation (Madison, WI). The SYBR Green PCR master mix was purchased from Qiagen, Inc. (Valencia, CA). Random and specific primers were purchased from Operon Biotechnologies, Inc. (Huntsville, $\mathrm{AL})$.

\section{Animals and Diets}

All procedures involving animals were approved by the Agricultural Animal Care and Use Committee of The Ohio State University. The experiment was designed as a crossover design with two 22-d periods. Eight multiparous Holstein cows were fed a common diet (Table 1) for a 21-d preliminary period. At the end of the preliminary period, cows were $162 \pm 35$ DIM and produced $40 \pm 2 \mathrm{~kg} / \mathrm{d}$ of milk. At the end of the experiment, 6 of the 8 cows were pregnant and the average days of gestation for cows that were pregnant was 82 . All cows were randomly assigned to 1 of 2 sequences of treatments (control to biotin, and biotin to control). Treatments consisted of experimental diets (Table 1) with 0 (control) or $0.96 \mathrm{mg}$ (biotin) of supplemental biotin per kilogram of DM. The concentration of supplemental biotin was selected to supply $20 \mathrm{mg} / \mathrm{d}$ based on an estimated DMI of $22 \mathrm{~kg} / \mathrm{d}$. The diet was formulated to meet nutrient requirements (NRC, 2001) for a $650-\mathrm{kg}$ lactating dairy cow producing $40 \mathrm{~kg}$ of milk/ d. High proportions of grain in the substrate decreased microbial biotin synthesis in vitro (Abel et al., 2001); therefore, we formulated the basal diet to contain a high proportion of concentrate (60\% DM basis). Supplemental biotin (Rovimix Biotin; DSM Nutritional Products Inc., Parsippany, NJ) was supplied in the pelleted concentrate mix. Cows were housed in individual tie stalls and fed once daily (0400 h). Diets were offered
Table 1. Ingredients and nutrient composition (\%, DM basis) of the basal diet

\begin{tabular}{lcc}
\hline Item & Preliminary & Experimental $^{1}$ \\
\hline Ingredient & & \\
Corn silage & 20.7 & 12.1 \\
Alfalfa silage & 31.1 & 30.4 \\
Corn grain, dry and ground & 17.4 & 20.7 \\
Corn gluten meal & 8.0 & 9.6 \\
Soybean hulls & 13.7 & 16.3 \\
Soybean meal, 44\% CP & 6.4 & 7.7 \\
Fat, animal and vegetable blend & 0.8 & 1.0 \\
Urea & 0.1 & 0.1 \\
Sodium bicarbonate & 0.6 & 0.8 \\
Minerals and vitamins & 1.2 & 1.4 \\
Chemical analysis & & \\
CP & 20.6 & 20.6 \\
NDF & 33.4 & 33.5 \\
Starch & 19.9 & 19.4 \\
\hline
\end{tabular}

${ }^{1}$ The experimental diet with supplemental biotin contained $0.0048 \%$ of biotin premix ( $20 \mathrm{mg} / \mathrm{g}$ of Rovimix H-2; DSM Nutritional Products Inc., Parsippany, NJ), which replaced a similar amount of corn gluten meal. The diet contained $0.38 \%$ dicalcium phosphate, $0.58 \%$ limestone, $0.01 \%$ magnesium oxide, $0.20 \%$ trace mineral salt, $0.15 \%$ selenium $(200 \mathrm{mg} / \mathrm{kg}), 0.0023 \%$ zinc sulfate, $0.0012 \%$ copper sulfate, 3,000 IU/kg of vitamin A, $870 \mathrm{IU} / \mathrm{kg}$ of vitamin $\mathrm{D}$, and 21 $\mathrm{IU} / \mathrm{kg}$ of vitamin $\mathrm{E}$.

ad libitum ( $\sim 5 \%$ feed refusals, as-fed basis) as mixed rations. The amount of feed offered and refused was measured daily. Diets were adjusted weekly for changes in ingredient DM concentration. Cows were milked twice daily (0200 and $1300 \mathrm{~h}$ ) and milk weights were recorded electronically at each milking. The average of the daily milk yields and DMI from d 14 to 20 was used for statistical analysis. Cows were weighed on d 21 of each period at $0800 \mathrm{~h}$.

\section{Sample Collection and Analysis}

Samples of feed and feed refused were collected once weekly. Aliquots of feed and feed refusal samples were dried in a forced-air oven for $24 \mathrm{~h}$ at $100^{\circ} \mathrm{C}$. A second aliquot of feed was stored at $-20^{\circ} \mathrm{C}$ until analysis. Forage samples were lyophilized and all feed samples were ground to pass through a 1-mm screen of a Wiley mill (Arthur H. Thomas, Philadelphia, PA). Ground samples were analyzed for DM $\left(24 \mathrm{~h}\right.$ at $\left.100^{\circ} \mathrm{C}\right)$, NDF (Ankom ${ }^{200}$ Fiber Analyzer; Ankom Technology, Fairport, NY) with sodium sulfite and $\alpha$-amylase (Ankom Technology), CP (AOAC, 1990), and starch (Weiss and Wyatt, 2000).

Milk samples (a.m. and p.m. milkings) were collected on $\mathrm{d} 10$ and 17 for determination of milk fat, protein, and lactose concentrations with a B2000 Infrared Analyzer (Bentley Instruments, Chaska, MN) by DHI Cooperative, Inc. (Columbus, $\mathrm{OH}$ ). An additional milk sample (p.m. milking), and blood and urine samples were collected on $d 20$. Concentrations of avidin-binding substances (ABS) in the milk, plasma, and urine were de- 
termined (Ferreira et al., 2007). Crude liver homogenates (described below) were diluted (1:20) before a single-step competitive enzyme-binding assay (Ridascreen Biotin kit; R-Biopharm GmbH, Darmstadt, Germany) to measure ABS. Urine was also analyzed for creatinine (Di Giorgio, 1974). Samples of rumen fluid were collected on d 20 approximately $2 \mathrm{~h}$ postfeeding via a stomach tube. Rumen fluid was processed and analyzed for VFA (Zimmerly and Weiss, 2001).

\section{Liver Biopsies}

On d 21 of each period, liver tissue was collected by percutaneous liver biopsy. Liver biopsies were performed while cows were restrained in a chute. After clipping, locating liver parenchyma and large blood vessels by ultrasonography $(5 \mathrm{MHz}$ linear probe, Aloka $500 \mathrm{~V}$; Aloka, Wallingford, CT), and appropriately scrubbing the area, $10 \mathrm{~mL}$ of $2 \%$ lidocaine hydrochloride was injected at the 11th and 12th intercostal space. After making a 2-cm incision, a sterile biopsy instrument (5-mm i.d.) was directed toward the opposite elbow and inserted through the muscle and peritoneal tissue into the liver. After retracting the biopsy instrument, the incision was closed with suture staples. Two aliquots of liver tissue were immediately rinsed with sterile $0.9 \% \mathrm{NaCl}$ solution, placed in a sterile plastic vial, snap-frozen in liquid $\mathrm{N}$, and stored at $-80^{\circ} \mathrm{C}$.

\section{Activity of Biotin-Dependent Carboxylases}

Thawed liver tissue $(0.86 \pm 0.22 \mathrm{~g}$, wet weight $)$ was homogenized and subjected to sonication as described by Zempleni et al. (1997). Aliquots of the resulting supernatant (i.e., liver homogenate) were snap-frozen in liquid $\mathrm{N}$ and stored at $-80^{\circ} \mathrm{C}$ until $\mathrm{ABS}$, enzyme activity, and protein assays were conducted. Protein concentrations in liver homogenates were determined in triplicate according to the method of Bradford, using BSA as a protein standard. The coefficient of variation among triplicates was 5.3\%.

Activity of PCC was determined by measuring the fixation of ${ }^{14} \mathrm{CO}_{2}$ according to Zempleni et al. (1997), with modifications. Briefly, $5 \mu \mathrm{L}$ of liver homogenate was vortex-mixed with $100 \mu \mathrm{L}$ of prewarmed $\left(30^{\circ} \mathrm{C}\right)$ incubation buffer. The incubation buffer (Suormala et al., 1985) contained $20 \mathrm{mmol} / \mathrm{L}$ of $\mathrm{NaH}\left[{ }^{14} \mathrm{C}^{\mathrm{O}} \mathrm{O}_{3}\right.$ (specific radioactivity $125 \mu \mathrm{Ci} / \mathrm{mmol}), 100 \mathrm{mmol} / \mathrm{L}$ of Tris $(\mathrm{pH}=$ 8.0), $0.75 \mathrm{mmol} / \mathrm{L}$ of dithiothreitol, $6.0 \mathrm{mmol} / \mathrm{L}$ of $\mathrm{MgCl}_{2}$, $100 \mathrm{mmol} / \mathrm{L}$ of KCl, $3.14 \mathrm{mmol} / \mathrm{L}$ of disodium ATP, $1 \%$ Triton X-100 (vol/vol), and $1.0 \mathrm{mmol} / \mathrm{L}$ of propionylCoA. The mixture was incubated in a water bath at $30^{\circ} \mathrm{C}$ for $8 \mathrm{~min}$. The reaction was terminated by adding $20 \mu \mathrm{L}$ of $1 \mathrm{~mol} / \mathrm{L}$ of perchloric acid (vortex-mixed). A
100- $\mu \mathrm{L}$ aliquot was transferred into 5 -mL scintillation vials, dried in a dry bath at $55^{\circ} \mathrm{C}$ for approximately 2 $\mathrm{h}$ to remove unfixed $\mathrm{CO}_{2}$ (i.e., until a purplish residue was observed), and mixed with $4 \mathrm{~mL}$ of scintillation liquid (Ecolite+; MP Biomedicals, Irvine, CA). Fixed ${ }^{14} \mathrm{CO}_{2}$ was measured using a liquid scintillation analyzer (BS 6500; Beckman Coulter, Inc., Fullerton, CA). Final values were obtained after a 96 -h equilibration of the dried residue with the scintillation liquid.

Activity of PC was determined by measuring the fixation of ${ }^{14} \mathrm{CO}_{2}$ (Zempleni et al., 1997), with modifications. Briefly, $5 \mu \mathrm{L}$ of liver homogenate was vortexmixed with $100 \mu \mathrm{L}$ of prewarmed $\left(30^{\circ} \mathrm{C}\right)$ incubation buffer. The incubation buffer (Warren and Tipton, 1974) contained $15 \mathrm{mmol} / \mathrm{L}$ of $\mathrm{NaH}\left[{ }^{14} \mathrm{C}\right] \mathrm{O}_{3}$ (specific radioactivity $680 \mu \mathrm{Ci} / \mathrm{mmol}), 100 \mathrm{mmol} / \mathrm{L}$ of Tris $(\mathrm{pH}=$ 8.0), $5 \mathrm{mmol} / \mathrm{L}$ of $\mathrm{MgSO}_{4}, 0.1 \mathrm{mmol} / \mathrm{L}$ of acetyl-CoA, $0.1 \mathrm{mmol} / \mathrm{L}$ of reduced $\mathrm{NAD}$, malate dehydrogenase $(5$ units $/ \mathrm{mL}$ ), $1 \mathrm{mmol} / \mathrm{L}$ of disodium ATP, and $5 \mathrm{mmol} / \mathrm{L}$ of sodium pyruvate. The mixture was incubated in a water bath at $30^{\circ} \mathrm{C}$ for $5 \mathrm{~min}$. The reaction was terminated, and fixed ${ }^{14} \mathrm{CO}_{2}$ was measured as described above. Blank reactions were performed in all assays by omitting liver homogenate from the incubations. All samples were assayed in triplicate. The coefficients of variation among triplicates were 9.6 and $10.0 \%$ for PCC and $\mathrm{PC}$, respectively. All specific activities are expressed in nanomoles of total $\mathrm{CO}_{2}$ fixed per milligram of protein in $1 \mathrm{~min}$ at $30^{\circ} \mathrm{C}$.

\section{RNA Extraction}

Total RNA was isolated from liver tissue $(0.35 \pm 0.11$ $\mathrm{g}$, wet weight) using $4 \mathrm{~mL}$ of Trizol reagent following the manufacturer's instructions. Precipitated RNA was redissolved in $400 \mu \mathrm{L}$ of RNase-free water. Protein contamination of the isolated RNA was determined by the ratio of optical absorbance at 260 to $280 \mathrm{~nm}$, which averaged $1.66 \pm 0.05$.

\section{Quantification of mRNA}

The reverse-transcription reaction was performed using Super Script II reverse transcriptase following the manufacturer's instructions, but using RNasin as the ribonuclease inhibitor. To control for DNA contamination in the extracted RNA, reverse-transcription reactions were also performed without the addition of reverse transcriptase. No products were obtained.

Primers for PC, PCC, and cytosolic PEPCK were designed after obtaining bovine-specific mRNA sequences from the National Center of Biotechnology Information (Table 2). Primers were diluted to a working concentration of $15 \mu \mathrm{mol} / \mathrm{L}$. Quantitative real-time PCR was per- 
Table 2. Primer design for quantitative real-time PCR

\begin{tabular}{lllr}
\hline Gene $^{1}$ & Accession no. & \multicolumn{1}{c}{ Primer sequence } & Position \\
\hline PC & NM_177946 & F 5'-CATGCGCTTCCTGTACGAGT-3' & 1,846 \\
& & R 5'-CGCAGAACTTGAAGACCACA-3' & 1,991 \\
PCC & CB223151 & F 5'-GAGGACACAAGCAGCATTCT-3' & 250 \\
& & R 5'-GCAGGTCTCCTTCTCCAACT-3' & 454 \\
PEPCK & NM_174737 & F 5'-TCCTTGGGAAGAAGTGCT-3' & 388 \\
& & R 5'-CGGGAGAGTAGGGTTCAT-3' & 572 \\
GAPDH & NM_001034034 & F 5'-AAGATTGTCAGCAATGCC-3' & 499 \\
& & R 5'-ACAGACACGTTGGGAG-3' & 791 \\
\hline
\end{tabular}

${ }^{1} \mathrm{PC}=$ pyruvate carboxylase; $\mathrm{PCC}=$ propionyl-coenzyme A carboxylase; $\mathrm{PEPCK}=$ phosphoenolpyruvate carboxykinase.

formed in 96-well plates by incubating $2 \mu \mathrm{L}$ of reversetranscription product with $0.5 \mu \mathrm{L}$ of forward primer, $0.5 \mu \mathrm{L}$ of reverse primer, $10 \mu \mathrm{L}$ of SYBR Green PCR master mix, and $7 \mu \mathrm{L}$ of RNAse-free water. Quantitative real-time PCR was performed in a continuous fluorescence detector (DNA Engine Opticon 2 System; BioRad Laboratories, Inc., Waltham, MA) using the following temperatures and times per cycle ( 40 cycles): denaturation at $94^{\circ} \mathrm{C}$ for $30 \mathrm{~s}$, annealing at $54^{\circ} \mathrm{C}$ for $30 \mathrm{~s}$, and extension at $72^{\circ} \mathrm{C}$ for $60 \mathrm{~s}$. The first cycle was preceded by denaturation at $95^{\circ} \mathrm{C}$ for $15 \mathrm{~min}$. Nonspecific amplification was not evidenced by the melting curve analysis and agarose-gel electrophoresis. Primer pairs were also validated after sequencing the amplified product. For each gene, all samples $(n=16)$ were amplified in triplicate and in one plate (i.e., within-run replication). Expression of the genes for PC, PCC, and PEPCK were normalized to that of GAPDH (Table 2).

\section{Statistical Analysis}

All variables were analyzed using the MIXED procedure of SAS (SAS Institute, 2004). The model included cow (random, $7 \mathrm{df}$ ), period (random, $1 \mathrm{df}$ ), and residual error (random, $6 \mathrm{df}$ ).

\section{RESULTS}

Biotin supplementation did not affect DMI, milk yield, or milk composition (Table 3). Consistent with

Table 3. Production measures of cows consuming a diet containing either 0 (control) or $0.96 \mathrm{mg} / \mathrm{kg}$ of DM of supplemental biotin (biotin)

\begin{tabular}{lcccc}
\hline Item & Control & Biotin & SEM & $P$-value \\
\hline BW, kg & 746 & 752 & 14 & 0.13 \\
DMI, kg/d & 27.9 & 28.3 & 1.3 & 0.23 \\
Milk yield, kg/d & 39.1 & 39.3 & 2.3 & 0.82 \\
Milk fat, \% & 3.59 & 3.66 & 0.34 & 0.52 \\
Milk true protein, \% & 3.30 & 3.32 & 0.08 & 0.73 \\
Milk lactose, \% & 4.80 & 4.83 & 0.06 & 0.50 \\
\hline
\end{tabular}

previous studies (Zimmerly and Weiss, 2001; Ferreira et al., 2007), biotin supplementation did not affect molar proportions of VFA in the rumen (59.7, 22.2, 13.8, $0.8,2.4$, and $1.1 \mathrm{~mol} / 100 \mathrm{~mol}$ of VFA for acetate, propionate, butyrate, isobutyrate, valerate, and isovalerate, respectively; data not shown). Biotin supplementation increased $(P<0.01)$ the concentration of ABS in plasma, milk, and urine but not in liver (Table 4). Biotin supplementation increased $(P<0.08)$ the activity of PC but did not affect $(P>0.20)$ the activity of PCC in liver tissue (Figure 1). Biotin supplementation did not affect $(P>0.30)$ expression of the genes for PC, PCC, and PEPCK (Figure 2).

\section{DISCUSSION}

Biotin is a required cofactor for 4 carboxylase enzymes, 2 of which (PC and PCC) are directly involved in glucose synthesis. In a dairy cow, the peripheral glucose supply comes almost exclusively from gluconeogenesis (Reynolds et al., 1994). Because the glucose supply to the mammary gland is a major determinant of milk yield, increased activity of PC and PCC could explain the increased milk yield often observed when biotin is supplemented. The pathway for glucose synthesis from lactate, glycerol, and alanine involves PC, whereas PCC is needed to synthesize glucose from propionate. In this study, biotin supplementation increased $(P<0.08)$ the activity of hepatic PC but had no effect on PCC. In rats that were marginally or clinically deficient in biotin, activities of both hepatic PC (Rodriguez-Melendez et al., 2001) and hepatic PCC (Rodriguez-Melendez et al., 2001; Mock and Mock, 2002) were depressed. Zempleni and Mock (1999) suggested that in nonruminants, PCC activity may be more responsive than PC activity to changes in biotin status because of the importance of PC in central metabolic pathways. However, in ruminants, propionate is the major precursor of glucose. In dairy cattle near peak production (83 DIM), about $66 \%$ of the net glucose released from the liver came from propionate, whereas only $10 \%$ came 
Table 4. Concentrations of avidin-binding substances (ABS) in plasma, milk, urine, and liver of cows consuming a diet with either 0 (Control) or $0.96 \mathrm{mg} / \mathrm{kg}$ DM of supplemental biotin (Biotin)

\begin{tabular}{lcccc}
\hline Item & Control & Biotin & SEM & $P$-value \\
\hline Plasma ABS, nmol/L & 3.48 & 4.95 & 0.34 & 0.01 \\
Milk ABS, nmol/L & 109.7 & 329.5 & 32.6 & 0.01 \\
Urine ABS, nmol/mmol of creatinine & 84.1 & 179.5 & 19.2 & 0.01 \\
Liver ABS, pmol/mg of protein & 1.05 & 1.06 & 0.11 & 0.91 \\
\hline
\end{tabular}

from lactate, glycerol, and alanine combined (Reynolds et al., 2003). Because of the importance of propionate for glucose synthesis, PCC may have a higher priority for biotin than $\mathrm{PC}$ in ruminants, thus explaining the different treatment effects on the activities of $\mathrm{PC}$ and PCC. The activities of PC and PCC (Figure 1) were similar to those previously reported for dairy cows (Murondoti et al., 2004), but were substantially greater than those reported in the liver of rats (Zempleni et al., 1997).

Because biotin supplementation did not affect expression of the gene for PC (Figure 2), the increased activity of PC may be attributed to an increased activation of apocarboxylase into holocarboxylase (Rodriguez-Melendez et al., 2001; Solorzano-Vargas et al., 2002) by action of the enzyme holocarboxylase synthetase (HCS) or to limited availability of biotin to biotinylate apocarboxylases (Sealey et al., 2005). Rodriguez-Melendez et al. (2001) observed a lower activity of PC in the liver of biotin-deficient rats, whereas the mRNA abundance for PC in the liver was similar between biotin-deficient and biotin-sufficient rats. Rodriguez-Melendez et al. (2001) and Solorzano-Vargas et al. (2002) reported that biotin deficiency decreased the mRNA abundance of HCS in rats and humans. In this study we attempted to measure the abundance of HCS mRNA as a marker

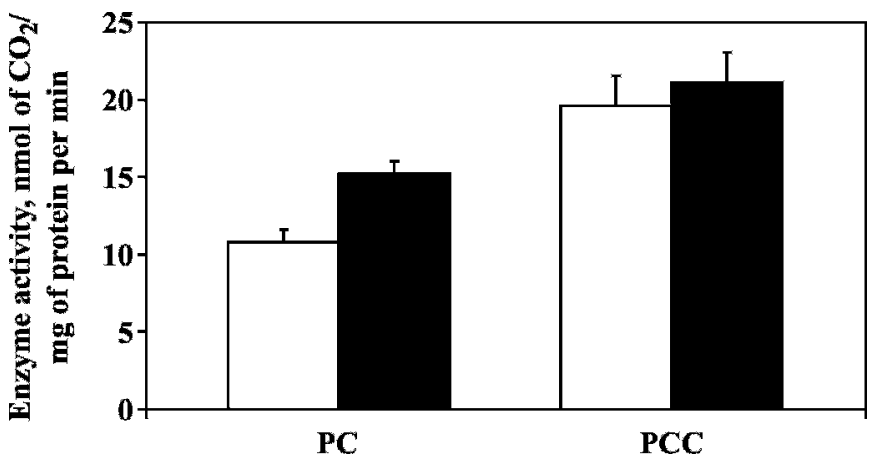

Figure 1. Enzyme activity (nmol of $\mathrm{CO}_{2} / \mathrm{mg}$ of protein per min) of pyruvate carboxylase (PC) and propionyl-coenzyme A carboxylase (PCC) in the liver of lactating dairy cows. Cows were fed a diet containing either 0 (open bars) or $0.96 \mathrm{mg} / \mathrm{kg}$ of DM (solid bars) of supplemental biotin. Values are means \pm SEM. Diet effect: PC $(P<$ $0.08)$; PCC $(P<0.21)$. of HCS activity, but no message amplification was obtained using 3 different primer pairs. Sealey et al. (2005) reported lower abundances of holocarboxylases in biotin-deficient than in biotin-sufficient mice (similar observations for dams and fetuses), whereas the mRNA abundances did not differ. They suggested that biotin deficiency results in a lack of available biotin to biotinylate apocarboxylases.

Contrary to our second hypothesis, biotin supplementation did not affect the expression of PEPCK in the liver of lactating dairy cows. We based our hypothesis on the assumption that an increased activity of PEPCK would be required for conversion of the additional oxaloacetate (i.e., the presumed result of increased activities of PCC and PC). Accordingly, Baird and Young (1975) indicated that the activity of PEPCK in the liver of dairy cows responded to dietary changes (50 vs. $100 \%$ of concentrate in the diet), likely in response to an increased load of propionate to the liver. Biotin supplementation may not have increased the substrate load enough to increase the activity of PEPCK. Also, the mRNA abundance of PEPCK may not be an adequate indicator of PEPCK activity. Agca et al. (2002) reported a correlation between mRNA abundance of cytosolic PEPCK and PEPCK activity in adult dairy cows; how-

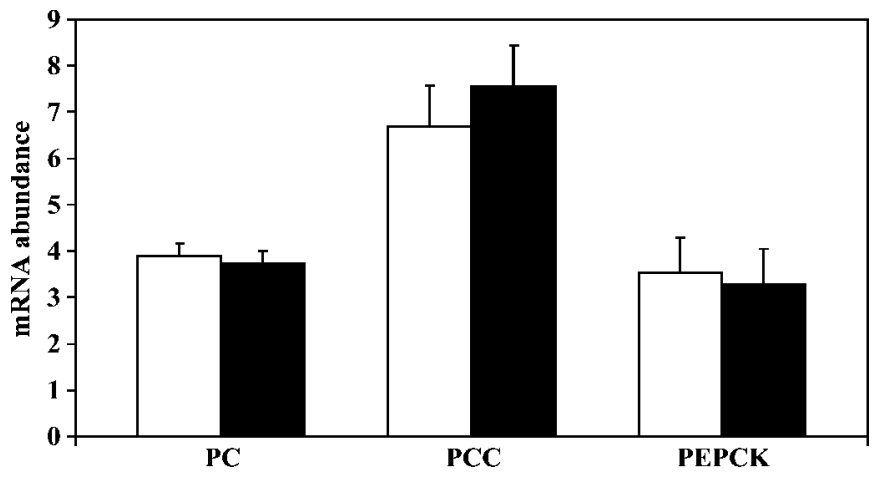

Figure 2. Gene expression (arbitrary units) of pyruvate carboxylase (PC), propionyl-coenzyme A carboxylase (PCC), and phosphoenolpyruvate carboxykinase (PEPCK) in the liver of lactating dairy cows. Cows were fed a diet containing either 0 (open bars) or $0.96 \mathrm{mg} / \mathrm{kg}$ of DM (solid bars) of supplemental biotin. Abundance of mRNA was normalized using GAPDH. Values are means \pm SEM. Diet effects for all genes $(P>0.30)$. 
ever, Hammon et al. (2005) reported no such correlation in milk-fed calves.

Biotin supplementation increased the concentration of ABS in plasma and milk (Table 4), similar to previous data (Zimmerly and Weiss, 2001; Rosendo et al., 2004; Ferreira et al., 2007). Biotin supplementation also doubled the concentration (per mmol of creatinine) of ABS in urine. In a companion study (Ferreira et al., 2007) using different cows but similar diets, plasma and milk concentrations were approximately 1.7 and 3.5 times higher for cows fed supplemental biotin compared with control cows. In the current study, plasma and milk concentrations in cows receiving the biotin supplement were 1.4 and 3 times higher than those of control cows. Cows in this study weighed approximately $100 \mathrm{~kg}$ more than those in the previous study; thus, increased basal metabolism (i.e., maintenance) and increased volume of distribution may account for the differences between the 2 experiments. The concentration of free ABS in liver tissue was not affected by biotin supplementation (Table 4). Liver homogenates were not subjected to acid or enzymatic hydrolysis; therefore, biotin that was bound to enzymes would not have been measured. Lewis et al. (2001) reported that rats fed a control diet (nonsupplemented) or a biotin-supplemented diet had similar concentrations of free biotin in the liver. Biotin is transported into human hepatocytes by a sodiumdependent transporter that has a Michaelis constant in the micromolar range (Said et al., 1994). Based on this transport system, biotin uptake by the liver should likely be related to the biotin concentration in plasma. Reidling and Said (2006) observed that biotin uptake by intestinal cells is upregulated during biotin deficiency, suggesting that a mechanism exists to maintain biotin homeostasis. The presence of a similar homeostatic mechanism in the liver could also explain the similar concentration of ABS in liver tissue.

Although biotin supplementation increased the activity of PC, it had no effect on any production measures (Table 3). This could mean that the increase in PC activity for cows fed biotin was not great enough to elicit a milk yield response or that something other than PC activity (i.e., glucose synthesis) was limiting milk production. However, this experiment was designed primarily to examine dietary effects on liver enzymes, and the number of observations is small for production data. In studies using more animals, biotin supplementation has often increased milk production (Zimmerly and Weiss, 2001; Majee et al., 2003; Ferreira et al., 2007). In addition, the liver biopsies at the end of the first period may have influenced intake and milk production during the second period. The effect of period could not be evaluated statistically because it was considered random. However, average milk yield was 4.2 $\mathrm{kg} / \mathrm{d}$ lower and average DMI was $2.2 \mathrm{~kg} / \mathrm{d}$ lower in period 2 than in period 1 .

Residual or carryover effects may affect interpretations when a sequence of treatments is applied to the same subject, such as in the case of a crossover design. Whether carryover of biotin existed in this experiment is not certain, but seems unlikely. Frigg et al. (1993) measured the clearance of an oral dose of biotin (40 $\mathrm{mg}$ ) in dairy heifers and observed that the biotin concentration in plasma returned to baseline concentrations $72 \mathrm{~h}$ after dosing. Accordingly, during period 2, the concentrations of ABS in the plasma, milk, and urine of cows consuming the control diet were similar to those of cows consuming the control diet during period 1 . Weinberg and Utter (1979) reported that the half-life for PC in the rat liver was $4.6 \mathrm{~d}$. Assuming that this value is similar for carboxylases in the liver of dairy cows, a residual effect on the enzyme activity also would be unlikely.

In conclusion, biotin supplementation did not affect the activity of PCC and expression of the genes for PCC, PC, and PEPCK in the liver of lactating dairy cows but increased the activity of PC. The differential response to biotin supplementation suggests that compared with PC, PCC may have a higher priority for biotin in cattle. Although the activity of PC was increased by biotin supplementation, no response was observed in milk yields. This could be a result of the experimental design or it could be that the change in PC activity was not large enough or that something other than glucose synthesis limited milk yields. However, data from this experiment suggest that when biotin is supplemented, the increase in milk production observed in some studies may be related to an increase in biotin-dependent carboxylases. Whether biotin supplementation increases glucose production in the liver still needs to be evaluated.

\section{ACKNOWLEDGMENTS}

Appreciation is extended to Juliette Hanson for her assistance with the liver biopsies and to the crew of Krauss Dairy Center at the Ohio Agricultural Research and Development Center for day-to-day cow management and for their assistance with liver biopsies. Gratitude is also extended to Janos Zempleni for his guidance on enzyme activity assays and to Jodi Winkler for her assistance with quantitative real-time PCR. Salaries and research support were provided by state and federal funds appropriated to the Ohio Agricultural Research and Development Center, The Ohio State University (Manuscript No. 11-06AS). 


\section{REFERENCES}

Abel, H., I. Immig, C. Da Costa Gomez, and W. Steinberg. 2001. Research note: Effect of increasing dietary concentrate levels on microbial biotin metabolism in the artificial rumen simulation system (RUSITEC). Arch. Anim. Nutr. 55:371-376.

Agca, C., R. B. Greenfield, J. R. Hartwell, and S. S. Donkin. 2002. Cloning and characterization of bovine cytosolic and mitochondrial PEPCK during transition to lactation. Physiol. Genomics $11: 53-63$.

AOAC. 1990. Official Methods of Analysis. 15th ed. AOAC, Arlington, VA.

Baird, G. D., and J. L. Young. 1975. The response of key gluconeogenic enzymes in bovine liver to various dietary and hormonal regimes. J. Agric. Sci. (Camb.) 84:227-230.

Di Giorgio, J. 1974. Nonprotein nitrogenous constituents. Pages 503563 in Clinical Chemistry: Principles and Techniques. 2nd ed. R. J. Henry, D. C. Cannon, and J. W. Winkelman, ed. Harper \& Row, New York, NY.

Ferreira, G., W. P. Weiss, and L. B. Willett. 2007. Changes in measures of biotin status do not reflect milk yield responses when dairy cows are fed supplemental biotin. J. Dairy Sci. 90:14521459 .

Frigg, M., O. C. Straub, and D. Hartmann. 1993. The bioavailability of supplemental biotin in cattle. Int. J. Vitam. Nutr. Res. 63:122-128.

Hammon, H. M., C. Philipona, Y. Zbinden, J. W. Blum, and S. S. Donkin. 2005. Effects of dexamethasone and growth hormone treatment on hepatic gluconeogenic enzymes in calves. J. Dairy Sci. 88:2107-2116.

Keech, D. B., and M. F. Utter. 1963. Pyruvate carboxylase. II. Properties. J. Biol. Chem. 238:2609-2614.

Lewis, B., S. Rathman, and R. McMahon. 2001. Dietary biotin intake modulates the pool of free and protein-bound biotin in rat liver. J. Nutr. 131:2310-2315.

Majee, D. N., E. C. Schwab, S. J. Bertics, W. M. Seymour, and R. D. Shaver. 2003. Lactation performance by dairy cows fed supplemental biotin and B-vitamin blend. J. Dairy Sci. 86:2106-2112.

Mock, D. M., and N. I. Mock. 2002. Lymphocyte propionyl-CoA carboxylase is an early and sensitive indicator of biotin deficiency in rats, but urinary excretion of 3-hydroxy-propionic acid is not. J. Nutr. 132:1945-1950.

Murondoti, A., R. Jorritsma, A. C. Beynen, T. Wensing, and M. J. Geelen. 2004. Activities of the enzymes of hepatic gluconeogenesis in periparturient dairy cows with induced fatty liver. J. Dairy Res. 71:129-134.

NRC. 2001. Nutrient Requirements of Dairy Cattle. 7th ed. National Academy Press, Washington, DC.

Reidling, J. C., and H. M. Said. 2006. In vitro and in vivo characterization of the minimal promoter of the human intestinal biotin trans- porter hSMVT: Adaptive regulation of the biotin uptake process. Gastroenterology 130:68. (Abstr.)

Reynolds, C. K., P. C. Aikman, B. Lupoli, D. J. Humphries, and D. E. Beever. 2003. Splanchnic metabolism of dairy cows during the transition from late gestation through early lactation. J. Dairy Sci. 86:1201-1217.

Reynolds, C. K., D. L. Harmon, and M. J. Cecava. 1994. Absorption and delivery of nutrients for milk protein synthesis by portal drained viscera. J. Dairy Sci. 77:2787-2808.

Rodriguez-Melendez, R., S. Cano, S. T. Mendez, and A. Velazquez. 2001. Biotin regulates the genetic expression of holocarboxylase synthetase and mitochondrial carboxylases in rats. J. Nutr. 131:1909-1913.

Rosendo, O., C. R. Staples, L. R. McDowell, R. McMahon, L. Badinga, F. G. Martin, J. F. Shearer, W. M. Seymour, and N. S. Wilkinson. 2004. Effects of biotin supplementation on peripartum performance and metabolites of Holstein cows. J. Dairy Sci. 87:25352545 .

Said, H. M., T. Y. Ma, and V. S. Kamanna. 1994. Uptake of biotin by human hepatoma cell line, Hep G2: A carrier-mediated process similar to that of normal liver. J. Cell. Physiol. 161:483-489.

SAS Institute. 2004. SAS/STAT User's Guide, Version 9. SAS Institute Inc., Cary, NC.

Sealey, W. M., S. L. Stratton, D. M. Mock, and D. K. Hansen. 2005 Marginal maternal biotin deficiency in CD-1 mice reduces fetal mass of biotin-dependent carboxylases. J. Nutr. 135:973-977.

Solorzano-Vargas, R. S., D. Pacheco-Alvarez, and A. Leon Del Rio. 2002. Holocarboxylase synthetase is an obligate participant in biotin-mediated regulation of its own expression and of biotindependent carboxylases mRNA levels in human cells. Proc. Natl. Acad. Sci. USA 99:5325-5330.

Suormala, T., H. Wick, J. P. Bonjour, and E. Regula-Baumgartner 1985. Rapid differential diagnosis of carboxylase deficiencies and evaluation for biotin-responsiveness in a single blood sample. Clin. Chim. Acta 1985:151-162.

Warren, G. B., and K. F. Tipton. 1974. Pig liver pyruvate carboxylase. Purification, properties and cation specificity. Biochem. J. 139:297-310.

Weinberg, M. B., and M. F. Utter. 1979. Effect of thyroid hormone on the turnover of rat liver pyruvate carboxylase and pyruvate dehydrogenase. J. Biol. Chem. 254:9492-9499.

Weiss, W. P., and D. J. Wyatt. 2000. Effect of oil content and kernel processing of corn silage on digestibility and milk production by dairy cows. J. Dairy Sci. 83:351-358.

Zempleni, J., and D. M. Mock. 1999. Biotin biochemistry and human requirements. J. Nutr. Biochem. 10:128-138.

Zempleni, J., T. A. Trusty, and D. M. Mock. 1997. Lipoic acid reduces the activities of biotin-dependent carboxylases in rat liver. J. Nutr. 127:1776-1781.

Zimmerly, C. A., and W. P. Weiss. 2001. Effects of supplemental dietary biotin on performance of Holstein cows during early lactation. J. Dairy Sci. 84:498-506. 